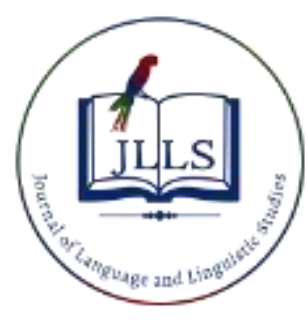

Available online at www.jlls.org

JOURNAL OF LANGUAGE AND LINGUISTIC STUDIES

ISSN: 1305-578X

Journal of Language and Linguistic Studies, 16(2), 912-929; 2020

\title{
Learners' oral corrective feedback perceptions and preferences in Thai as a foreign language tertiary setting
}

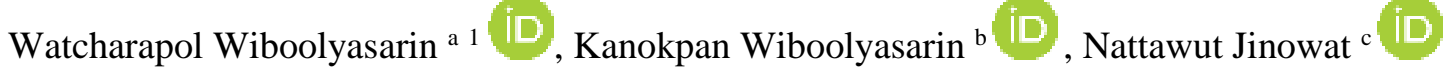 \\ ${ }^{a}$ Suan Dusit University, Bangkok, Thailand \\ ${ }^{b}$ Chandrakasem Rajabhat University, Bangkok, Thailand \\ APA Citation: \\ ${ }^{c}$ Suan Sunandha Rajabhat University, Bangkok, Thailand
}

Wiboolyasarin, W., Wiboolyasarin, K., \& Jinowat, N. (2020). Learners' oral corrective feedback perceptions and preferences in Thai as a foreign language tertiary setting. Journal of Language and Linguistic Studies, 16(2), 912-929.

Submission Date: 14/04/2020

Acceptance Date: $30 / 05 / 2020$

\begin{abstract}
The goal of this research is to investigate the existence of perceptions and preferences among East Asian undergraduate students of Thai. To fill this gap, ninety-nine L2 learners having experience of studying Thai speaking courses at five universities completed an online questionnaire reporting on their recognitions and attitudes. The findings revealed that recast was the most frequently perceived strategy of oral corrective feedback (OCF) that Thai as a foreign language (TFL) students were provided. Explicit correction was the most favoured technique in TFL teaching situations. In a speech, they inclined to be provided with the error correction in private places and would like to be corrected by peers. Considering in terms of the nationalities. An analysis further suggested that some OCF opinions between Chinese and the Korean learners were similar; they tended to prefer clarification request and repetition techniques. In contrast, inattention to error, peer correction, and error correction in public were less preferable among them.
\end{abstract}

(C) 2020 JLLS and the Authors - Published by JLLS.

Keywords: corrective feedback; perceptions; preferences; second language; East Asian students

\section{Introduction}

Wiliam describes feedback as 'information given to individuals or groups about their own preference' $(2018$, p. 5). In other words, feedback is more productive when it provides reassurance to learners whether they are on the right track. Oral feedback, at its simplest, will be the form of reactions to learners' spoken words that contain errors (Ellis, Loewen, \& Erlam, 2006). The last decades have seen a proliferation of empirical research investigating the nature of corrective feedback and the connection between self-reported perceptions and actual performances. Within oral corrective feedback (hereafter, OCF), it may either result in learners' modified output (Şakiroğlu, 2020) or cause humiliate and embarrass in learners (Ölmezer-Öztürk \& Öztürk, 2016).

\footnotetext{
${ }^{1}$ Corresponding author. Tel.: +66-090-992-4000

E-mail address: watcharapol_wib@dusit.ac.th
} 
The current study examines learners' OCF perceptions and preferences concerning their different cultural backgrounds. Although the vast number of research on L2 students' beliefs and practices received extensive coverage in the second language field (e.g., Bitchener \& Knoch, 2010; Brown, 2016; Li \& Iwashita, 2019; Wang \& Loewen, 2015), the literature on learners' perceptions in particularly languages other than English is limited. Rather, less has been focused on corrective feedback in minority-language contexts. It requires us to draw attention to one particular area: whether L2 students of Thai as a foreign language (TFL) perceive and prefer the existence of OCF in the class. The present study, therefore, surveys the perceptions and preferences in which a group of ninety-nine international students has studied Thai language in East Asian countries and considers how differences among classroom contexts influence these students' attitudes towards OCF.

\subsection{Literature review}

OCF is viewed as an 'instructional strategy of L2 teaching' in second language acquisition (Spada, 2013). The study of OCF's role in the L2 classroom has been a much-discussed topic over the past five decades. Since the late 1970s there have been numerous observational studies of OCF in L2 classrooms investigating questions concerning how much OCF lecturers given, in what settings, and whether some mistakes acquired more awareness than others (p. 140). The general findingss (e.g. Chaudron, 1977; Fanselow, 1977) suggested that the greatest amount of OCF was devoted to errors, and an inclination for L2 teachers to give more OCF earlier rather than later in the students' improvement. In the 1990s few studies highlighted on OCF in the L2 classroom. Lyster \& Ranta (1997), for example, identified six strategies supplied by instructors and students' instant replies to them. The results revealed that a recast was the most frequently techniques that led to few immediate student responses and corrections. It suggested that learners may not have been aware of the recasts as repairs in nature. In other classroom studies of OCF, students' instant reactions to recasts of Sheen (2004) have been more frequent and brought about higher levels of corrections. Even though the literature has demonstrated that recasts are the most frequently applied strategy of OCF (Fu \& Nassaji, 2016; Lyster \& Mori, 2006). However, this is not the case across all instructional contexts, as it has been found in Ur's (2012) studies, the recast is the least effective in producing uptake since students perhaps does not realise it as a repair. Myriads of studies conducted by Lyster (e.g. Lyster, 2004) point out that the most productive OCF requires negotiations and active contribution from the students. Thus, elicitations, repetitions or metalinguistic feedback are significantly better than recasts. According to Yang (2016), the efficacy of OCF techniques on L2 learning is relevant to how learners become aware of the OCF. There however remains a need for future studies to examine the influence of OCF in connection with learner age and L1 background (Spada, 2013)

\subsubsection{OCF in the L2 classroom}

The salience of OCF from the cognitive viewpoint plays a pivotal role in drawing learners' attention to form. The attention contributes to allow students to detect some differences between their faulty utterances and the correct models. Different techniques can be applied to give OCF in the classroom. Lyster and Ranta (1997) studied the variety of techniques in an error treatment sequence, and the six strategies of OCF were indicated according to the use of the teachers (see Table 1). Ur (2012), likewise, proposed the same list of six techniques that had been observed in actual lessons as followings: explicit correction, recast, clarification request, metalinguistic comment, elicitation, and repetition. 
Table 1. Techniques for correcting error in Lyster and Ranta (1997)

\begin{tabular}{|l|l|}
\hline Technique & Description \\
\hline Explicit correction & $\begin{array}{l}\text { The instructors give the form, they obviously identify that what the student had } \\
\text { said was erroneous }\end{array}$ \\
\hline Recasts & $\begin{array}{l}\text { The instructors' reformulation of all or part of a student's utterance, minus the } \\
\text { error. }\end{array}$ \\
\hline Clarification request & $\begin{array}{l}\text { The instructors indicate students either that their utterance has been wrong or that } \\
\text { the utterance is inaccurate in some way and that a repetition or a reformulation is } \\
\text { required. }\end{array}$ \\
\hline Metalinguistic feedback & $\begin{array}{l}\text { The instructors give either comments, information, or questions concerning the } \\
\text { well-formedness of the student's spoken word, without explicitly supplying the } \\
\text { correct form. }\end{array}$ \\
\hline Elicitation & The instructors use to directly elicit the accurate model from the learners. \\
\hline Repetition & The instructors' repetition, in isolation, of the student's incorrect utterance. \\
\hline
\end{tabular}

In 2007 Ranta and Lyster subsequently classified into two extensive OCF classifications: reformulations and prompts. The former consists of recasts and explicit correction as these techniques provide students with reformulations of their non-target output. The latter comprises various signals that encourage learners to self-correct (clarification request, elicitati4on, metalinguistic comments, and repetition). Drawing on this category from the arguments of Ellis (2017); Lyster, Saito, and Sato (2013); Sheen and Ellis (2011), a similar taxonomy of OCF moves, which account for two key dimensions: input prompting (i.e., gives the correct linguistic model) and output prompting (i.e., pushes the students to self-repair) as well as implicit (i.e., the corrective force remains hidden) and explicit (i.e., the corrective force is in a very understandable way). Descriptions of the difference moves can be found in Table 2.

Table 2. A classification of OCF strategies (Based on Ellis, 2017; Lyster, Saito, \& Sato, 2013; Sheen \& Ellis, 2011)

\begin{tabular}{|c|c|c|}
\hline & Implicit & Explicit \\
\hline $\begin{array}{l}\text { Input providing/ } \\
\text { reformulations }\end{array}$ & $\begin{array}{l}\text { 1. conversational recasts: a reformulation } \\
\text { of a learner's spoken word to resolve a } \\
\text { communication failure }\end{array}$ & $\begin{array}{l}\text { 2. Didactic recasts: a reformulation of a } \\
\text { learner utterance in the absence of a } \\
\text { communication problem } \\
\text { 3. Explicit correction: a reformulation of } \\
\text { a learner utterance and a clear indication } \\
\text { of an error } \\
\text { 4. Explicit correction with metalinguistic } \\
\text { explanation: as described in item 3., plus } \\
\text { metalinguistic comment }\end{array}$ \\
\hline $\begin{array}{l}\text { Output providing/ } \\
\text { prompts }\end{array}$ & $\begin{array}{l}\text { 5. Repetition: a verbatim repetition of a } \\
\text { learner utterance, usually with adjusted } \\
\text { intonation to call attention to the error } \\
\text { 6. Clarification request: a phrase such as } \\
\text { 'Pardon', 'I beg your pardon', 'I don't } \\
\text { understand' following a learner utterance } \\
\text { to indirectly alert an error }\end{array}$ & $\begin{array}{l}\text { 7. Metalinguistic comments: a short } \\
\text { metalinguistic statement aimed at } \\
\text { obtaining a self-repair from the learner } \\
\text { 8. Elicitation: a directly elicits a self- } \\
\text { repair from the learner, usually in the } \\
\text { form of a wh- question } \\
\text { 9. Paralinguistic signal: an attempt to } \\
\text { non-verbally evoke the correct model } \\
\text { from the student }\end{array}$ \\
\hline
\end{tabular}




\subsubsection{Learners' OCF perceptions and preferences}

Despite the varied techniques of providing OCF, L2 lecturers may supply OCF that is not effective or, perhaps, does not match the learners' preferences. Several studies have investigated and revealed contradictory results. For instance, university-level Japanese EFL students in the work of Katayama (2007) had strongly favourable attitudes towards OCF and pointed out a preference for correction of pragmatic errors rather than other types of mistakes. This partly collaborates with the results of research among ESL learners carried out by Bang (1999); Ozmen and Aydin (2015); Schulz (2001); Yang (2016). Lee's study in 2016 confirmed that the majority of EFL students in a US university preferred to get plentiful OCF from their teachers. Additionally, Alhaysony's (2016) findings showed that all students had similar perceptions concerning OCF and preferred OCF in English oral communication courses. However, EFL students of Ölmezer-Öztürk and Öztürk (2016) felt uncomfortable when they were edited with instant feedback and the consecutive use of it by lecturers persuaded learners against speaking in a classroom atmosphere. As witnessed by the evidence, the research on learner perceptions and preferences regarding OCF is limited in both EFL and ESL settings. There remains a need for studies to investigate the existence of OCF in the context of learner perceptions and preferences in TFL context.

\subsection{Research questions}

To this end, examining the OCF perspective in TFL instruction will contribute to a more comprehensive analysis of OCF as an L2 facilitator in language curriculum practices and teachers' engagement. This study not only probes students' perceptions as far as their preferences of OCF are concerned but also explores the three different classroom contexts, intending to answer the following research questions:

1. Is there the perception of OCF while learning Thai as a foreign language?

2. To what extent are the OCF preferences of TFL learners?

3. Do TFL learners' nationalities influence their OCF preferences?

\section{Method}

\subsection{Context and participants}

A total of ninety-nine foreign undergraduate students (seventy-six females and twenty-three males) of five different overseas universities from three countries: the People's Republic of China, the Republic of Korea, and Japan, served as respondents based on accidental and snowball samplings. The samples were chosen from those who had previous experience of studying Thai speaking-related courses in their own universities with non- and native Thai instructors. Reported by their lecturers, they were basic users according to the TFL context. These higher education institutes employed both full-time and part-time TFL teachers; foreign instructors of Thai worked in permanent positions, whereas native Thai speakers, who were considered reliable sources of teaching pronunciation or speaking, were hired as temporary staffs to help make students comfortably intelligible to native Thai listeners. To be allowed access to participants, friends and acquaintances of the researchers who had worked as visiting lecturers of Thai at anonymous universities were contacted via either Line or WeChat application to distribute an email with an introductory letter and web-based questionnaire attachment to their L2 undergraduates. In addition to this, participating students were requested to forward the email to other potential respondents who, too, met the requirement of having enrolled in any oral communication courses. Table 3 presents the demographic data describing the year of study at universities and the age. 
Table 3. Demographic data of respondents

\begin{tabular}{llcccc}
\hline Background & & $\begin{array}{c}\text { Chinese } \\
(\mathrm{n}=44)\end{array}$ & $\begin{array}{c}\text { Korean } \\
(\mathrm{n}=24)\end{array}$ & $\begin{array}{c}\text { Japanese } \\
(\mathrm{n}=31)\end{array}$ & $\begin{array}{c}\text { Total } \\
(\mathrm{n}=99)\end{array}$ \\
\hline Year of study & Freshman & 11 & 5 & 2 & 18 \\
& Sophomore & 5 & 12 & 0 & 17 \\
& Junior & 23 & 0 & 12 & 35 \\
Age & Senior & 5 & 7 & 17 & 29 \\
& 18 & 2 & 1 & 0 & 3 \\
& 19 & 1 & 2 & 1 & 4 \\
& 18 & 18 & 8 & 4 & 30 \\
& 21 & 2 & 6 & 9 & 33 \\
& 22 & 3 & 3 & 12 & 18 \\
\hline
\end{tabular}

As indicated in the table, a group of participants were Chinese $(n=44)$, while other nationalities included Japanese $(n=31)$ and Korean $(n=24)$. Of the students who participated in the study, 35 were juniors, 29 were seniors, 18 were freshmen, and 17 were sophomores. The age of these participating students ranged between 18-23 years. Three were 18 years old, four were 19 years old, thirty were 20 years old, thirty-three were 21 years old, eighteen were 22 years old, and eleven were 23 years old. All of them reported to have TFL knowledge and have experienced in a Thai speaking-related class.

\subsection{Survey and procedure}

The internet-based questionnaire was distributed to participating students during July 2019. All of the questions were written both in English and Thai to facilitate an understanding of L2 learners of Thai. A total of 25 open- and closed-ended questions elicited information on three principal areas. It started with a demographic section (5 questions) from which the above information was retrieved. Following this, respondents were asked to respond to 6 question items, extracted from different OCF types of Lyster \& Ranta (1997) and Ur (2012), on their OCF perceptions. The other 14 statements were reflected OCF preferences; eight items were phrased to indicate relative inclinations toward teachers' practices regarding OCF and six were phrased to identify tendencies for OCF in Thai speaking classes. Dichotomous, short answer, multiple-choice, and rating scale questions were included. In terms of reliability and validity, an even number scaling system was used to avoid respondents to choose a midpoint. As Cohen, Manion, \& Morrison (2018) argue, East Asian participants, who were taught a Confucian doctrine of the mean, tend to opt for the mid-point of a 5-point scale. It should also be noted that choosing an even number of scale points requires a decision on rating and we could infer that those who selected 1,2, or 3 were in some measure of disagreement, while those respondents who indicated 4,5 , or 6 were agreeing with the statement. That would help display a measure of (dis)agreement.

The questionnaire was utterly anonymous; neither name of students nor whoever was required. The researcher's acquaintances were contacted and explained a brief introduction, aim, and procedure or the nature of the research activities as well as being requested to invite their L2 learners of Thai to take part in the study. The participant's individual consent and data were gathered through a web-based survey hosted on SoGoSurvey.

A preliminary study was implemented with twenty potential participants to determine the internal consistency reliability. The overall Cronbach's alpha coefficient for this questionnaire survey was 0.796 as demonstrated in Table 4, indicating a reliable level (Cohen, Manion, \& Morrison, 2018, p. 774). 
Table 4. Reliability analysis for OCF items

\begin{tabular}{ccc}
\hline Item & Corrected item-total correlation & Cronbach Alpha if item deleted \\
\hline$(1)$ & .222 & .797 \\
$(2)$ & .426 & .783 \\
$(3)$ & .457 & .781 \\
$(4)$ & .402 & .785 \\
$(5)$ & .417 & .784 \\
$(6)$ & .317 & .791 \\
$(7)$ & -.104 & .834 \\
$(8)$ & .537 & .779 \\
$(9)$ & .478 & .783 \\
$(10)$ & .472 & .783 \\
$(11)$ & .390 & .786 \\
$(12)$ & .771 & .769 \\
$(13)$ & .413 & .784 \\
$(14)$ & .228 & .795 \\
$(15)$ & .036 & .806 \\
$(16)$ & .460 & .782 \\
$(17)$ & .628 & .776 \\
$(18)$ & .506 & .778 \\
$(19)$ & .515 & .780 \\
$(20)$ & .387 & .788 \\
\hline
\end{tabular}

Cronbach Alpha for the twenty items $=.796$

Calculating for each item of the scale, as presented above, the values ranged between 0.769 and 0.834 , revealing that internal consistency would improve if one of the following items was omitted. It was clear, however, that the item-total correlations for item (1), item (7), and item (15) were considerably lower than all the other correlations, the researchers reconsidered and decided to redefine the statements.

The bilingual questionnaire was distributed to participating students during July 2019. All items were written both in English and Thai to facilitate an understanding of L2 learners of Thai. In connection to this, linguistic terminologies, loaded or ambiguous words, and jargon or studious details were avoided. A total of twenty-five open- and closed-ended questions elicited information on three principal areas. Dichotomous (for gender and TFL experience), multiple-choice (for year of study, age, and nationality), rating scale (for perceptions and preferences), and short answer questions (for additional suggestion) were included. It started with a demographic section (five questions) from which the above information was retrieved. Following this, respondents were asked to respond to six question items, extracted from different OCF types of Lyster and Ranta (1997); Ur (2012), on their OCF perceptions. The other fourteen statements were reflected OCF preferences; eight items were phrased to indicate relative inclinations towards teachers' practices regarding OCF and six were phrased to identify tendencies for OCF in Thai speaking classes.

An even number scaling system is used to refrain from choosing a mid-point. The six-point-scale questionnaire is not new. In light of Lee's (2016) study, this type of survey questionnaire was also used to examine how learners' prior EFL classes in their own countries influenced their beliefs and viewpoints towards their American lecturers' OCF. As Cohen, Manion, and Morrison (2018) argue, East Asian participants, who are taught a Confucian doctrine of the mean, tend to opt for the mid-point of a 
five-point scale (p. 484). It should also be pointed out here that choosing an even number of scale points requires a decision on rating, and we can infer that those who select one, two, or three are in some measure of disagreement, while those respondents who indicate four, five, or six are agreeing with the statement. That will help display a measure of (dis)agreement.

\subsection{Data analysis}

The questionnaire used a six-point Likert scale, with 6 corresponding to always, very good, or strongly agree and 1 to never, very bad, or strongly disagree based on aspects of questions. Quantitative data from the internet survey were automatically calculated by SoGoSurvey, which reported average scores on a scale from one to six. Throughout, the questionnaire responses were entered into IBM SPSS Statistics 22 for statistical analysis. Both descriptive and inferential statistics (a one-way ANOVA test and a Bonferroni correction) were conducted to decide whether there are any statistically significant differences across - and presented separately by - three ethnic groups.

\section{Results}

\subsection{Learner perceptions}

The first part asked the L2 learners about their perceptions of OCF in Thai speaking classes. To present these results, students' self-reported perceptions of OCF are represented in Table 5.

Table 5. Learner perceptions of OCF in Thai speaking courses

\begin{tabular}{|c|c|c|c|c|c|}
\hline \multirow[t]{2}{*}{ Theme } & \multicolumn{4}{|c|}{ Mean score $^{1}$} & \multirow{2}{*}{$\begin{array}{l}P \text { value } \\
\text { One-way } \\
\text { ANOVA }\end{array}$} \\
\hline & $\begin{array}{l}\text { Chinese } \\
(\mathrm{n}=44)\end{array}$ & $\begin{array}{l}\text { Korean } \\
(\mathrm{n}=24)\end{array}$ & $\begin{array}{c}\text { Japanese } \\
(\mathrm{n}=31)\end{array}$ & Total average & \\
\hline (1) recasts & 4.70 & 4.46 & 5.16 & 4.79 & .162 \\
\hline (2) elicitation & 4.66 & 4.45 & 5.13 & 4.76 & .225 \\
\hline (3) clarification request & 4.14 & 4.13 & 5.26 & 4.48 & $.003 *$ \\
\hline (4) metalinguistic clues & 4.57 & 4.46 & 5.03 & 4.69 & .212 \\
\hline (5) explicit correction & 4.43 & 4.67 & 5.19 & 4.73 & .100 \\
\hline (6) repetition & 3.77 & 4.25 & 5.23 & 4.34 & $.000 *$ \\
\hline
\end{tabular}

${ }^{1}$ where $1.00-1.82$ = never; $1.83-2.65$ = rarely; $2.66-3.48$ = sometimes; $3.49-4.32$ = often; $4.33-5.16$ = usually; $5.17-$ $6.00=$ always

$* p<.05$

As shown, most students usually acknowledged the correct form of oral mistake from their teachers $(M=4.79, S D=1.40)$ and thought that they were generally supportive of self-correction for an error ( $M$ $=4.76, S D=1.51)$. Learners were aware that lecturers made an error explicit and told accurate information $(M=4.73, S D=1.52)$, including further clarification of grammar and linguistic terms for use $(M=4.69, S D=1.34)$. On the contrary, an additional explanation in the sense of the word was required by lecturers $(M=4.48, S D=1.57)$ and their repetition of incorrect utterances implying that students were wrong in speaking $(M=4.34, S D=1.55)$ received low mean rating when comparing to other five statements.

One-way ANOVAs were performed to find out whether there were statistically significant differences in perceptions about OCF. Statistical significance was set at the 0.05 level of probability. 
The dependent variables were the respondents' responses related to types of OCF ranging from one to six of the six question items, and the independent variables were the students' nationalities. Subsequently, a Bonferroni correction was run to see where the differences exactly lie. As illustrated in Figure 1, the tests show that statically significant differences regarding further elucidation of the unclear words $(F(2,96)=6.004, p<.05)$ and repetition by giving doubtful utterances $(F(2,96)=9.393, p<$ $.05)$ are found in their perceptions among different nationalities.

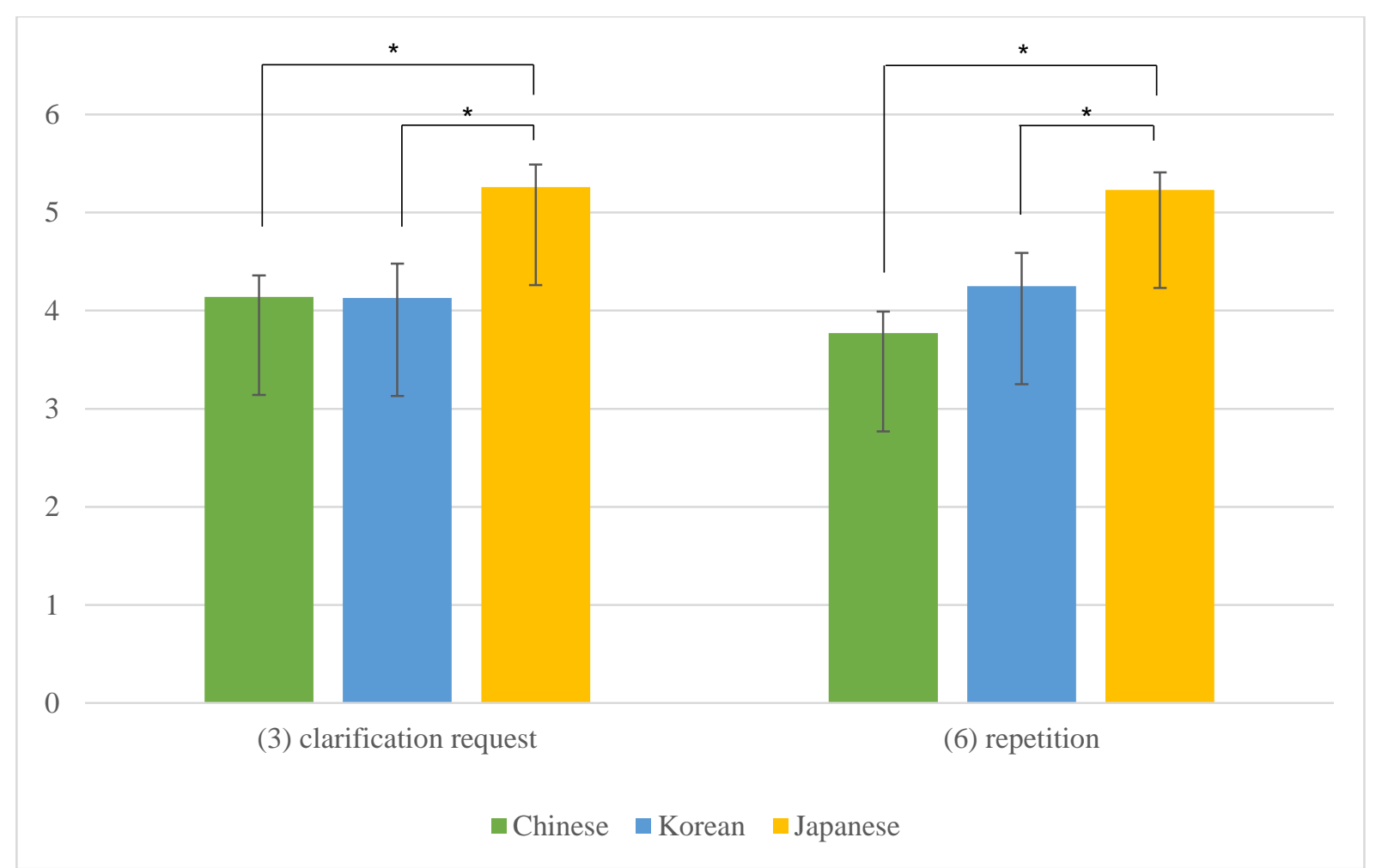

Figure 1. Means and standard errors for learners' perceptions regarding the type of OCF

Based on the results, there are some meaningful differences across the groups: Japanese and Chinese/Korean, and no difference was found between the Chinese and the Korean groups. It is shown that Chinese and Korean samples have similar perceptions concerning clarification request and repetition, whereas Japanese participants perceived these at higher level.

\subsection{Learner preferences}

The following section explored the participants' preferences of OCF in terms of teachers' actions.

Table 6. Learner preferences of OCF teachers' practices

\begin{tabular}{|c|c|c|c|c|c|}
\hline \multirow[t]{2}{*}{ Theme } & \multicolumn{4}{|c|}{ Mean score $^{2}$} & \multirow{2}{*}{$\begin{array}{c}P \text { value } \\
\text { One-way } \\
\text { ANOVA }\end{array}$} \\
\hline & $\begin{array}{l}\text { Chinese } \\
(\mathrm{n}=44)\end{array}$ & $\begin{array}{l}\text { Korean } \\
(n=24)\end{array}$ & $\begin{array}{c}\text { Japanese } \\
(\mathrm{n}=31)\end{array}$ & Total average & \\
\hline (7) inattention to error & 2.86 & 2.83 & 5.35 & 3.64 & $.000 *$ \\
\hline (8) elicitation & 4.93 & 4.83 & 5.54 & 5.10 & .055 \\
\hline (9) clarification request & 1.80 & 2.17 & 1.51 & 1.80 & .111 \\
\hline (10) explicit correction & 5.11 & 5.00 & 5.54 & 5.22 & .172 \\
\hline (11) peer correction & 3.84 & 3.70 & 5.51 & 4.33 & $.000 *$ \\
\hline
\end{tabular}




\begin{tabular}{|c|c|c|c|c|c|}
\hline \multirow[t]{2}{*}{ Theme } & \multicolumn{4}{|c|}{ Mean score ${ }^{2}$} & \multirow{2}{*}{$\begin{array}{l}P \text { value } \\
\text { One-way } \\
\text { ANOVA }\end{array}$} \\
\hline & $\begin{array}{l}\text { Chinese } \\
(\mathrm{n}=44)\end{array}$ & $\begin{array}{l}\text { Korean } \\
(\mathrm{n}=24)\end{array}$ & $\begin{array}{c}\text { Japanese } \\
(\mathrm{n}=31)\end{array}$ & Total average & \\
\hline $\begin{array}{l}\text { (12) metalinguistic } \\
\text { feedback }\end{array}$ & 5.05 & 4.88 & 5.58 & 5.17 & .052 \\
\hline (13) public correction & 3.93 & 3.91 & 5.55 & 4.43 & $.000^{*}$ \\
\hline (14) private correction & 4.70 & 5.04 & 5.32 & 4.98 & .111 \\
\hline
\end{tabular}

${ }^{2}$ where 1.00-1.82 = very bad; $1.83-2.65$ = bad; $2.66-3.48$ = fairly bad; $3.49-4.32$ = fairly good; $4.33-5.16$ = good; $5.17-6.00=$ very good

$* p<.05$

As summarised in Table 6, interestingly, the current participants preferred to be told what the mistakes were in their speaking and liked to be corrected by teachers $(M=5.22, S D=1.19)$. Consequently, once teachers merely informed that some error was made while speaking but not directly pointed out, L2 students of Thai tended to hold the least positive opinion about this intentional ambiguity $(M=1.80, S D=1.14)$. It was getting better at clarifying on errors and linguistic applications $(M=5.17$, $S D=1.17)$ than at being omitted. At least, to indicate that something went wrong, and a solution needed to be self-discovered by students was regarded as a good teacher's practice $(M=5.10, S D=1.27)$ in the learner preferences. Turning now to where respondents felt the most comfortable for receiving feedback, comparing the two situations: in public or in private, it was clear that personal meeting $(M=4.98, S D=$ 1.27) appeared likely to be more desirable than in-class announcement $(M=4.43, S D=1.49)$. The findings also claimed that students would like to be corrected by peers $(M=4.33, S D=1.58)$ rather than to be paid no attention to errors by teachers $(M=3.64, S D=2.02)$.

Similarly, as previously mentioned, one-way ANOVA and Bonferroni test were used to determine whether there were statistically significant differences in the learner preferences on OCF teachers' implementations among the three cohorts. In Figure 2, it is evident that the differences in the learner preferences are significant for three issues: (7) intentionally disregard for students' mistakes and rectification $(F(2,96)=24.089, p<.05),(11)$ peer correction $(F(2,96)=16.855, p<.05)$, and $(13)$ explicit correction in public $(F(2,96)=16.566, p<.05)$.

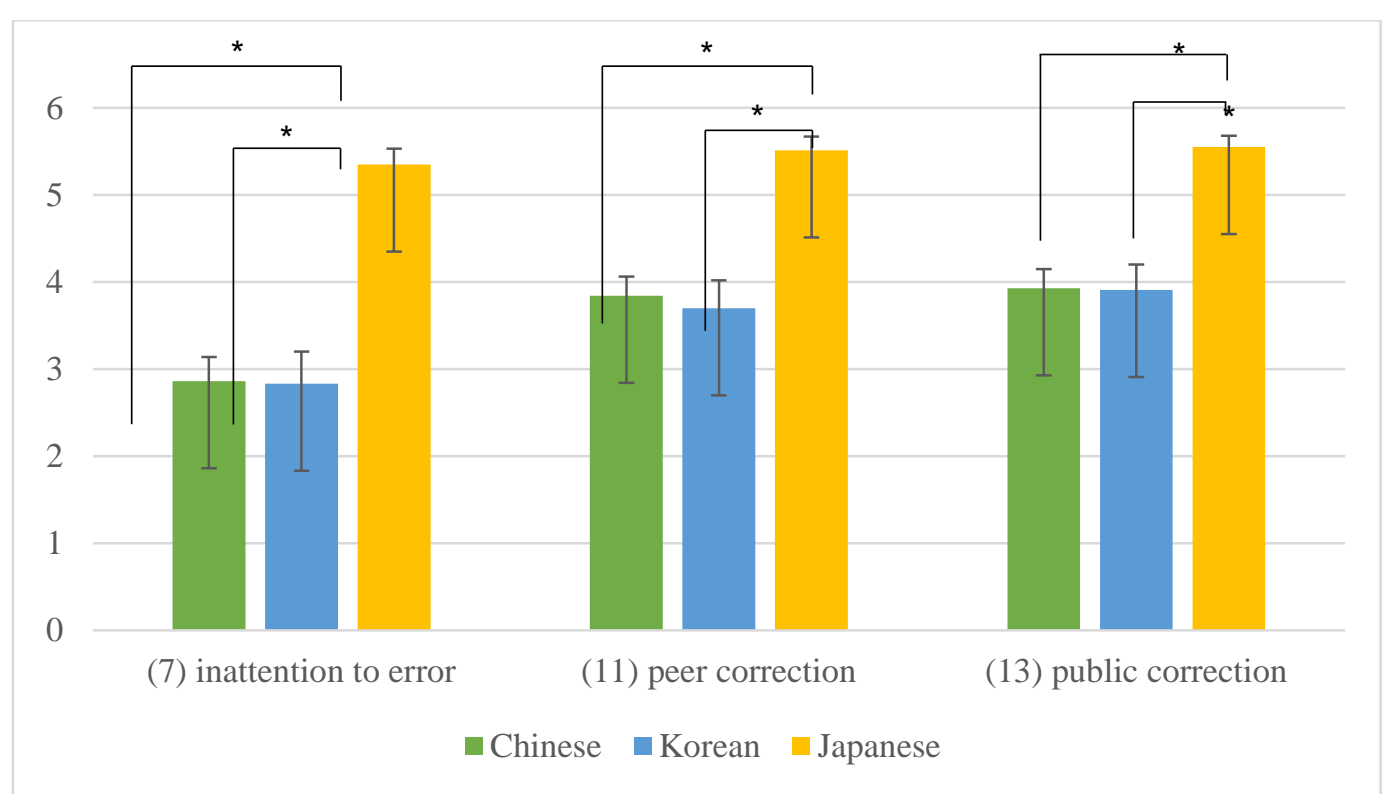

Figure 2. Means and standard errors for learners' preferences of OCF teachers' practices 
In sum, it is concluded that Chinese and Korean learners feel about their teachers' practices in a negative way in terms of paying no attention to students' error, asking peers to correct the mistake, and correct their errors publicly. In contrast, these teachers' performances are preferable for Japanese students.

Table 7. Learner preferences of OCF in Thai speaking classes

\begin{tabular}{|c|c|c|c|c|c|}
\hline \multirow[t]{2}{*}{ Theme } & \multicolumn{4}{|c|}{ Mean score ${ }^{3}$} & \multirow{2}{*}{$\begin{array}{l}P \text { value } \\
\text { One-way } \\
\text { ANOVA }\end{array}$} \\
\hline & $\begin{array}{l}\text { Chinese } \\
(\mathrm{n}=44)\end{array}$ & $\begin{array}{l}\text { Korean } \\
(\mathrm{n}=24)\end{array}$ & $\begin{array}{l}\text { Japanese } \\
(\mathrm{n}=31)\end{array}$ & Total average & \\
\hline (15) immediate feedback & 4.66 & 4.54 & 5.16 & 4.79 & .134 \\
\hline (16) all error correction & 4.32 & 4.25 & 5.23 & 4.59 & $.001 *$ \\
\hline $\begin{array}{l}\text { (17) extra assignment } \\
\text { works }\end{array}$ & 4.27 & 3.92 & 5.35 & 4.53 & $.000^{*}$ \\
\hline $\begin{array}{l}\text { (18) importance of error } \\
\text { correction }\end{array}$ & 5.09 & 5.00 & 5.45 & 5.18 & .270 \\
\hline $\begin{array}{l}\text { (19) increased motivation } \\
\text { to learn Thai }\end{array}$ & 4.81 & 4.88 & 5.23 & 4.96 & .285 \\
\hline $\begin{array}{l}\text { ( } 20) \text { positive emotion } \\
\text { wherever being corrected }\end{array}$ & 4.45 & 4.45 & 5.32 & 4.73 & $.004 *$ \\
\hline
\end{tabular}

${ }^{3}$ where 1.00-1.82 = strongly disagree; $1.83-2.65$ = disagree; $2.66-3.48$ = quite disagree; $3.49-4.32$ = quite agree; 4.33-5.16 = agree; $5.17-6.00=$ strongly agree

$* p<.05$

Based on attitudes, as seen in Table 7, a verbal correction was likely to be regarded as necessary to succeed in Thai speaking $(M=5.18, S D=1.13)$ in the highest level of measurement. The rest ranged between 4.59 and 4.96 with a value 'agree'. It could be claimed that OCF stimulated foreign learners' growing interests in learning Thai $(M=4.96, S D=1.13)$. If possible, lecturers promptly told the correct version of the student's erroneous utterance $(M=4.79, S D=1.27)$ or students seemed satisfied with a correction wherever feasible $(M=4.73, S D=1.23)$. In the same vein, every effort was made to rectify each of the errors $(M=4.59, S D=1.20)$ which ought to be emphasised in extra exercises or out-ofclassroom activities $(M=4.53, S D=1.37)$.

For statistical analysis, the one-way ANOVA and the Bonferroni method revealed three significant effects of ethnics in the learner preferences of OCF. As demonstrated in Figure 3, the tests on the same condition report that the correction of all errors $(F(2,96)=7.214, p<.05)$, the extra assignment works based on frequent mistakes $(F(2,96)=10.594, p<.05)$, and the strong inclination towards OCF regardless of location $(F(2,96)=5.832, p<.05)$ are found to have significant effects on OCF preferences. 


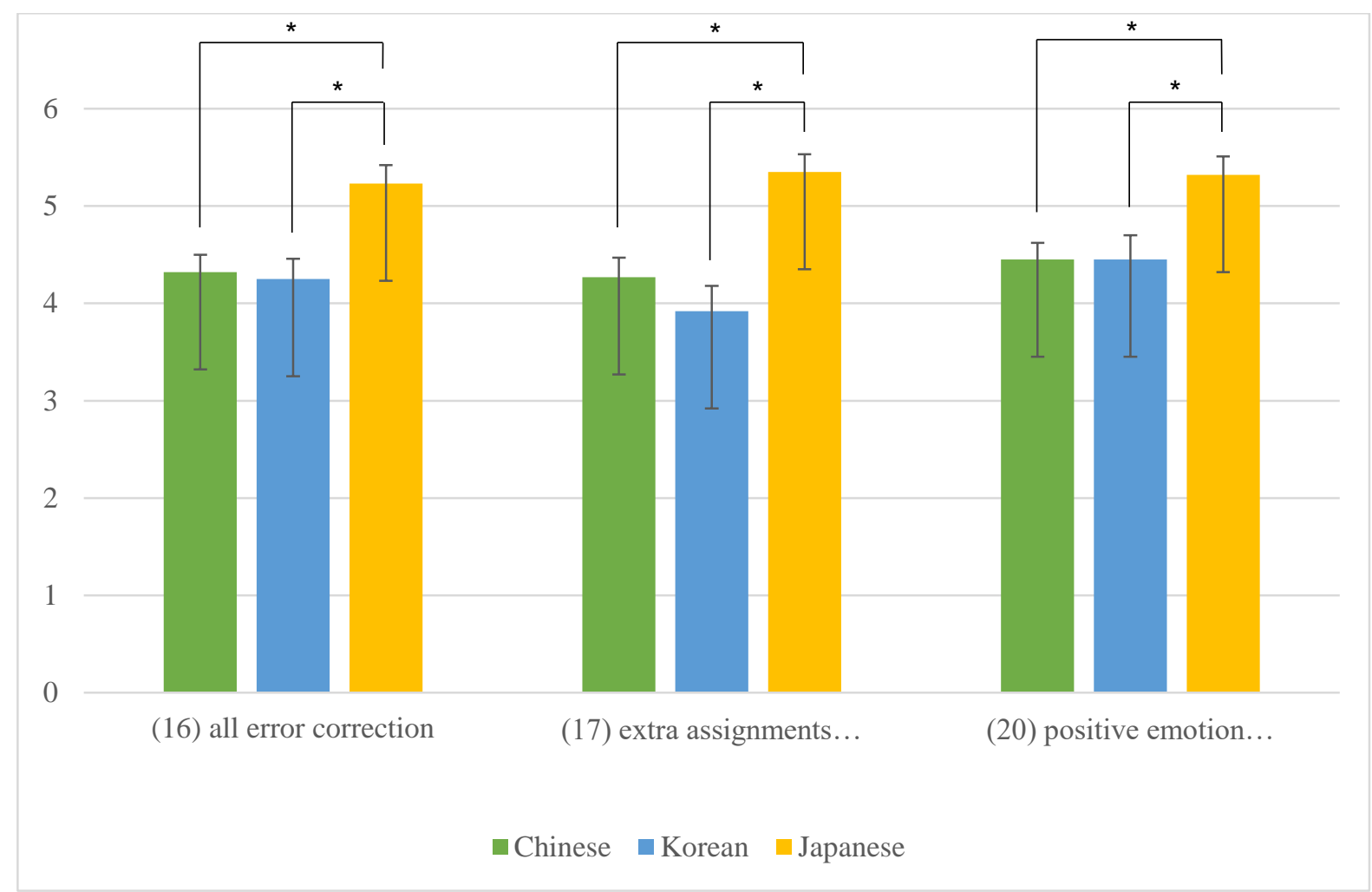

Figure 3. Means and standard errors for learners' preferences of OCF in Thai speaking classes

These findings indicated that the responses given by the Chinese and the Korean students tended to be similar in correcting all mistakes, assigning additional homework or exercise regarding frequent errors, and feeling positive about being told the mistakes explicitly. Again, the Japanese TFL learners were more in favour with these mentioned issues.

\section{Discussion}

The first research question focused on whether there were any OCF perceptions while learning Thai as a foreign language. A collective consideration of responses from the online questionnaires suggests that, in oral communication courses, L2 learners of Thai have perceived a variety of OCF types regularly provided in the classroom. It indicates that corrective feedback is regarded an essential aspect of second language pedagogy. It has been correspondent with definite evidence of Kurkgöz and Agcam's (2015) study, where participating teachers believed that OCF should not be abandoned and more than half of them immediately corrected whenever spoken error had been made. For learners, there is a clear tendency to indicate a perception of receiving OCF over having their error neglect. Öztürk's (2016) findings, for example, showed that $84 \%$ of errors were corrected in speaking classes, and only $16 \%$ of them received no feedback. It is highly likely that lecturers attempt to provide OCF to most of the erroneous spoken words made by their learners. Not surprisingly, learners become aware of the use of recast, in which corrections are strongly embedded in an interrupted communication flow, rather than any types. The notable OCF perception regarding the recasts - or immediate feedback - can be due to be easier to notice than any types and make very explicit on corrections; all - or parts - of erroneous utterances, as Lyter, Saito, and Sato (2013) note, are reformulated or dropped in a teacher-revised version. In Sheen's (2004) report, of all the feedback strategies, recasts (83\%) were the most frequently utilised in Korean L2 classrooms and in accordance with Panova and Lyster (2002), who investigated corrective techniques applied in Canada and found that recasts occurred in more than half of the 
feedback moves. This finding is parallel to finding obtained in other studies (e.g., Ahangari \& Amirzadeh, 2011; Lee, 2007; Lyster \& Mori, 2006).

The second research question addressed the student preferences of OCF teachers' practices. A quick glance at the illustration of the preferences in Table 6 suggests that students are likely to be told what is wrong and the correct version. In this vein, they are fascinated to hear either comments, information, or questions relevant to the error. Unless teachers were very explicit about corrections, students could be somewhat ambiguous. It can be said that these L2 students tend to have a favourable attitude to explicit correction and metalinguistic clue. It does not concur in Australia with Japanese learners in Yoshida's (2008) study. Seven students showed a preference for being devoted time to self-edit rather than receiving the accurate model. In the study, on the one hand, Japanese participants are less partial to search for and correct their own mistakes in which they feel very worst $(M=1.51)$ of the three groups in the case that teachers let them do so, but on the other hand it would be preferable if such teacher corrections were provided for them $(M=5.54)$. One possible explanation is in this study that the proficiency level of students may be, as mentioned earlier, at intermediate or above. In other words, highly proficient students want to receive more OCF as soon as the errors are made than low-proficient ones (Alhaysony, 2016). Findings of the previous studies, Ozmen and Aydin (2015) for example, suggested that participant's OCF preferences differed according to the language proficiency level of the learners, and both intermediate- and upper-intermediate-level learners preferred explicit OCF. From this finding, it can be inferred that higher-level learners incline towards explicit correction as they can significantly lighten the cognitive burden on self-correcting their own and turn attention to some grammatical metalanguage that refers to the nature of the error. As Ellis (2017) notes, the metalinguistic technique is seen as applicable to both accuracy and fluency work. Concerning the accuracy, these studies (Ammar \& Spada, 2006; Ellis, Loewen \& Erlan, 2006; Lyster 2004; Yang \& Lyster, 2010) reported that learners' accuracy in the use of grammatical features improved as a result of the OCF. In the present study, it would also be 'good' $(M=5.10)$ if L2 students were encouraged to self-correct (i.e. prompts) or, in other words, instructors unambiguously indicated the presence of an error and directed learners to think about alternative forms. Ammar and Spada, for example, state that high-proficient learners benefit equally from both prompts and reformulations. It has been argued that L2 learners' knowledge and performances may be particularly affected by the nature of the strategies applied to draw their attention to the formal attributes of the language. In terms of where errors should be corrected, oral errors ought to be, if plausible, corrected in one-on-one meetings rather than in class. Shyness may be the only explanation. In Paulhus, Duncan, and Yik's (2002) paper, the rates of self-reported shyness of Asian students, even for those born and raised in Western contexts, are higher than European learners. If so, it is worth looking at cultural influences, success in East Asia based mostly on academic performance (Loh \& Teo, 2017). To acknowledge the existence of errors may be interpreted that they have not achieved, lost confidence - especially for highly proficient learners, and their pride has been damaged. In classroom-based situation, they think they would also lose face if they admitted the mistakes in front of their peers. They 'quite agree' $(M=4.73)$ to feel positive no matter where they are when being alerted to the fact that an error has been committed.

Regarding learner preferences of OCF in TFL class, OCF has played a prominent role for universitylevel learners in TFL education. Faqeih (2015) highlights the fact that the students' attitudes towards OCF can affect their learning outcomes and influence on individuals' behaviours. As Gardner (1990) notes, favourable attitudes towards learning the language are one of three main elements of motivation in second or foreign language learning. As such, not surprisingly, students in the study 'quite agree' ( $M$ $=4.96$ ) with correcting an oral error which can increase students' motivation to continue to study Thai as a foreign language. Sheen (2006) argues that OCF attitudes cannot be expected to have any mediating effect unless learners perceive the correction. From the questionnaires, TFL learners, in general, 
responded that they 'usually' perceived six types of OCF in their Thai speaking classes. This means learners recognise the existence OCF in the classroom.

Concerning the timing of OCF provision, students concur with immediate feedback providing after the error has been made. In doing so, it will be of great benefit to these students. In an experimental study, Li, Zhu, and Ellis (2016) examined the comparative effectiveness of instant and delayed OCF on the learning of the English past passive construction by Chinese junior high school students. It was found that students with swift feedback tended to be at an advantage over those who received delayed feedback. There are theoretical grounds for preferring immediate feedback. Doughty (2001) notes that immediate feedback enables learners to map a specific form of the meaning it conveys in a window of opportunity (i.e., at that moment when the learners are struggling to express himself/herself). Lightbown's (1998) hypothesis posits that learning is context-dependent and that learners will be better able to remember grammatical rules and models in a communicative setting if they have received them in such a context. From this perspective, instant feedback is favoured since a focus on form is continuously integrated into learners' attempts to convey. Turning to the question of how many errors should be corrected, the results demonstrate that learners welcome all correction in general in which is corroborate the previous studies (e.g., Schulz, 2001)

Finally, the third question explored whether ethnic groups of learners exerted influence on OCF preferences. In general, L2 students' responses indicate high perceptions of OCF. Every type of OCF is usually perceived to be the technique for the three groups in which Japanese students recognise at the highest level. In contrast, Korean and Chinese learners detect on similar tiers, and there are statistically significant differences in clarification request and repetition between these groups which is consistent with Alhaysony (2016), while there are no significant differences in other statements. Each OCF that is slightly above the general level of the perceptions reflects that teachers of Thai use other techniques rather than relying on sole recast because some groups of students have a higher degree of proficiency; they can notice that there are teacher's strange utterance or teacher's direct question and understand them as implications of error. According to Lyster and Ranta (1997), self-correction moves (i.e., clarification and repetition) is more successful than recast technique for intermediate level. Teachers probably believe that their students who own a developed linguistic repertoire to assist them in editing themselves. As Kennedy (2010) argues, advanced learners are better able to correct their mistakes when they are got more opportunities to do.

It is clear from Figure 2 that there are statistically significant differences only for inattention to error, peer correction, and correction in public to which only two groups of students, Chinese and Korean, seem to be less inclined. As Ur (2012) explains, learners feel embarrassed or uncomfortable being edited by other peers and favour the more reliable source of the teacher. To be corrected by peers or teachers in public may cause embarrassment as stated previously. Another feasible explanation is that students place their trust in teachers rather than others; they have an inclination for their teacher to repair their oral mistakes. The result confirms the findings of Calsiyao (2015); Genc (2014); Zhang and Rahimi (2014).

\section{Conclusions}

The current study investigates the perceptions and preferences of OCF of ninety-nine foreign university students in Thai speaking classes. It was found that learners were typically aware of a variety of OCF when being corrected, and the frequency of different types of OCF was similar. The most typical ones are of recast, elicitation, and explicit correction, respectively. The findings of the current study also point out that there is a marked tendency for TFL learners to prefer receiving OCF to having their errors 
ignore. It indicates a high preference for explicit correction, metalinguistic feedback, and elicitation. Students express a very positive attitude that the correction of their oral error is crucial. Additionally, they expect the teacher to correct them as part of the typical classroom process and may not result in demoralisation or even antagonise. It is true that students do not really like being corrected by one another but prefer to get it from the teachers whom they do rely on and can provide the appropriate correction. Nevertheless, at the same time, although instructors need to provide OCF publicly for the whole class to benefit, it is essential to provide such feedback personally if possible. However, regardless of the location of OCF is given, they have yet got to be more positive about error correction. About preferences between the different ethnic groups in the study, there are statistically significant differences between Chinese/Korean and Japanese cohorts in terms of clarification request, repetition, inattention to error, peer correction, public correction, all error correction, addition assignment, and place for error correction.

The use of online questionnaires to capture the participants' perceptions and preferences has been a limitation since they have not a chance to convey opinions with their wordings or ideas. Interview data can yield a more comprehensive overview of their attitudes. Furthermore, it is also salient to note that TFL students in this study vary in degree of proficiency. Generally, to help establish visible patterns across studies of OCF in this context, there is a need for an upcoming volume of studies that address the students' proficiency which can influence the provision or the effectiveness of OCF in TFL teaching situations. Future research can build on a more nuanced understanding of teachers' feedback practices concerning specific linguistic features in instructional contexts contributing pedagogical and theoretical insight into the role of OCF in TFL classrooms.

\section{Ethics Committee Approval}

The author(s) confirm(s) that the study does not need ethics committee approval according to the research integrity rules in their country. (Date of Confirmation: April 17, 2020)

\section{References}

Ahangari, S., \& Amirzadeh, S. (2011). Exploring the teachers' use of spoken corrective feedback in teaching Iranian EFL learners at different levels of proficiency. Procedia - Social and Behavioral Sciences, 29, 1859-1868. DOI: 10.1016/j.sbspro.2011.11.435

Alhaysony, M. (2016). Saudi EFL preparatory year students' perception about corrective feedback in oral communication. English Language Teaching, 9(12), 47-61. DOI: 10.5539/let.v9n12p47

Ammar, A., \& Spada, N. (2006). One size fits all?: Recasts, prompts, and L2 learning. Studies in Second language Acquisition, 28(4), 543-574. DOI: 10.1017/S0272263106060268

Bang, Y.-J. (1999). Reactions of EFL students to oral error correction. Journal of Pan-Pacific Association of Applied Linguistics, 3, 39-51.

Bitchener, J., \& Knoch, U. (2010). Raising the linguistic accuracy level of advanced L2 writers with written corrective feedback. Journal of Second Language Writing, 19(4), 207-217. DOI: 10.1016/ j.jslw.2010.10.002

Brown, D. (2016). The type and linguistic foci of oral corrective feedback in the L2 classroom: A metaanalysis. Language Teaching Research, 20(4), 436-458. DOI: 10.1177/1362168814563200 
Calsiyao, I. S. (2015). Corrective feedback in classroom oral errors among Kalinga-Apayao State College students. International Journal of Social Science and Humanities Research, 3(1), 394-400.

Chaudron, C. (1977). A descriptive model of discourse in the corrective treatment of learners' errors. Language Learning, 27(1), 29-46. DOI: 10.1111/j.1467-1770.1977.tb00290.x

Cohen, L., Manion, L., \& Morrison, K. (2018). Research methods in education (8th ed.). New York: Routledge.

Doughty, C. (2001). Cognitive underpinnings of focus on form. In P. Robinson (Ed.), Cognition and second language instruction (pp. 206-257). Cambridge: Cambridge University Press.

Ellis, R. (2017). Oral corrective feedback in L2 classroom. In H. Nassaji \& E. Kartchava (Eds.), Corrective feedback in second language teaching and learning (pp. 3-18). New York: Routledge.

Ellis, R., Loewen, S., \& Erlam, R. (2006). Implicit and explicit corrective feedback and the acquisition of L2 grammar. Studies of Second Language Acquisition, 28(2), 339-368. DOI: 10.1017/S027 2263106060141

Fanselow, J. (1977). Beyond Rasomon - conceptualizing and describing the teaching act. TESOL Quarterly, 11(1), 17-39.

Faqeih, H. I. (2015). Learners' attitudes towards corrective feedback. Procedia-Social and Behavioral Sciences, 192, 664-671. DOI: 10.1016/j.sbspro.2015.06.101

Fu, T., \& Nassaji, H. (2016). Corrective feedback, learner uptake, and feedback perception in a Chinese as a foreign language classroom. Studies in Second Language Learning and Teaching, 6(1), 159181. DOI: $10.14746 /$ ssllt.2016.6.1.8

Gardner, R. C. (1990). Attitudes, motivation and personality as predictors of success in foreign language learning. In T. S. Parry \& C. W. Stansfield (Eds.), Language aptitude reconsidered. Englewood Cliffs, N.J.: Prentice Hall Regents.

Genc, Z. S. (2014). Correction spoken errors in English language teaching: Preferences of Turkish EFL learners at different proficiency levels. Education and Science, 39(174), 259-271. DOI: 10.15390/ EB.2014.1438

Hedge, T. (2000). Teaching and learning in the language classroom (Vol. 106). Oxford: Oxford University Press.

Katayama, A. (2007). Learners' perceptions toward oral error correction. In K. Bradford-Watts (Ed.), JALT2006 Conference Proceedings (pp. 284-299). Tokyo: JALT.

Kennedy, S. (2010). Corrective feedback for learners of varied proficiency levels: A teacher's choices. TESL Canada Journal, 27(2), 31-50. DOI: 10.18806/tesl.v27i2.1054

Kırkgöz, Y., \& Agcam, R. (2015). Teachers' perceptions on corrective feedback in Turkish primary schools. Procedia - Social and Behavioral Sciences, 192, 574-581. DOI: 10.1016/j.sbspro.2015. 06.096

Lee, E. J. (2016). Advanced ESL students' prior ESL education and their perceptions of oral corrective feedback. Journal of International Students, 6(3), 798-816.

Lee, J. (2007). Corrective feedback and learner uptake in English immersion classrooms at the primary level in Korea. English Teaching, 62(4), 311-334. DOI: 10.15858/engtea.62.4.200712.311. 
Li, H., \& Iwashita, N. (2019). The role of recasts and negotiated prompts in an FL learning context in China with non-English major university students. Language Teaching Research, 1-15. DOI: 10. $1177 / 1362168819839727$

Li, S., Zhu, Y., \& Ellis, R. (2016). The effects of the timing of corrective feedback on the acquisition of a new linguistic structure. The Modern Language Journal, 100(1), 275-295. DOI: 10.1111/ modl.12315

Lightbown, P. (1998). The importance of timing in focus on form. In C. Doughty \& J. Williams (Eds.), Focus of form in classroom second language acquisition (pp. 177-196). Cambridge: Cambridge University Press.

Loh, C. Y. R., \& Teo, T. C. (2017). Understanding Asian students learning styles, cultural influence and learning strategies. Journal of Education \& Social Policy, 7(1), 194-210.

Lyster, R. (2004). Differential effects of prompts and recasts in form-focused instruction. Studies in Second Language Acquisition, 26(3), 399-432. DOI: 10.1017/S0272263104263021

Lyster, R., \& Mori, H. (2006). Interactional feedback and instructional counterbalance. Studies in Second Language Acquisition, 28(2), 269-300. DOI: 10.1017/S0272263106060128

Lyster, R., \& Ranta, L. (1997). Corrective feedback and learner uptake: Negotiation of form in communicative classrooms. Studies in Second Language Acquisition, 19(1), 37-66. DOI: 10.1017/ S0272263197001034

Lyster, R., Saito, K., \& Sato, M. (2013). Oral corrective feedback in second language classrooms. Language Teaching Research, 46(1), 1-40. DOI: 10.1017/S0261444812000365

Ölmezer-Öztürk, E., \& Öztürk, G. (2016). Types and timing of oral corrective feedback in EFL classrooms: Voices from students. Novitas-ROYAL (Research on Youth and Language), 10(2), 113133.

Ozmen, K. S., \& Aydin, H. Ü. (2015). Examining student teachers' beliefs about oral corrective feedback: Insights from a teacher education program in Turkey. Australian Journal of Teacher Education, 40(12), 141-164. DOI: 10.14221/ajte.2015v40n12.10

Öztürk, G. (2016). An investigation on the use of oral corrective feedback in Turkish EFL classrooms. Journal of Language and Linguistic Studies, 12(2), 22-37.

Nassaji, H. (2016). Anniversary article international feedback in second language teaching and learning: A synthesis and analysis of current research. Language Teaching Research. 20(4), 535-562. DOI: $10.1177 / 1362168816644940$

Panova, I, \& Lyster, R. (2002). Patterns of corrective feedback and uptake in an adult ESL classroom. TESOL Quarterly, 36(4), 573-595. DOI: 10.2307/3588241

Paulhus, D. L., Duncan, J. H., \& Yik, M. S. M. (2002). Patterns of shyness in East-Asian and Europeanheritage students. Journal of Research in Personality, 36(5), 442-462. DOI: 10.1016/S00926566(02)00 005-3

Ranta, L., \& Lyster, R. (2007). A cognitive approach to improving immersion students' oral language abilities: The awareness-practice-feedback sequence. In R. DeKeyser (Ed.), Practice in a second language: Perspectives from applied linguistics and cognitive psychology (pp. 141-160). Cambridge: Cambridge University Press.

Şakiroğlu, H. Ü. (2020). Oral corrective feedback preferences of university students in English communication classes. International Journal of Research in Education and Science, 6(1), 172-178. 
Schulz, R. (2001). Cultural differences in student and teacher perceptions concerning the role of grammar instruction. The Modern Language Journal, 85(2), 244-258. DOI: 10.1111/00267902.00107

Sheen, Y. (2004). Corrective feedback and learner uptake in communicative classrooms across instructional settings. Language Teaching Research, 8(3), 263-300. DOI: 10.1191/136216 8804lr1460a

Sheen, Y. (2006). Exploring the relationship between characteristics of recasts and learner uptake. Language Teaching Research, 10(4), 361-392. DOI: 10.1191/13621688061r203oa

Sheen, Y., \& Ellis, R. (2011). Corrective feedback in language teaching. In E. Hinkel (Ed.), Handbook of research in second language teaching and learning (2nd ed.) (pp. 593-610). New York: Routledge.

Spada, N. (2013). Corrective feedback (oral). In P. Robinson (Ed.), The Routledge encyclopedia of second language acquisition (pp. 139-142). London: Routledge.

Ur, P. (2012). A course in English language teaching (2nd ed.). Cambridge: Cambridge University Press.

Wang, W., \& Loewen, S. (2015). Nonverbal behavior and corrective feedback in nine ESL universitylevel classrooms. Language Teaching Research, 20(4), 459-478. DOI: 10.1177/1362168 815577239

Wiliam, D. (2018). Feedback: At the heart of - but definitely not all of - formative. In A. A. Lionevich \& J. K. Smith (Eds.), The Cambridge handbook of instructional feedback. Cambridge: Cambridge University Press.

Yang, J. (2016). Learners' oral corrective feedback preferences in relation to their cultural background, proficiency level and types of error. System, 61, 75-86. DOI: 10.1016/j.system.2016.08.004.

Yang, Y., \& Lyster, R. (2010). Effects of form-focused practice and feedback on Chinese EFL learners' acquisition of regular and irregular past tense forms. Studies in Second Language Acquisition, 32(2), 235-263. DOI: $10.1017 /$ S0272263109990519

Yoshida, R. (2008). Teachers' choice and learners' preference of corrective-feedback types. Language Awareness, 17(1), 78-93. DOI: 10.2167/la429.0

Zhang, L. J., \& Rahimi, M. (2014). EFL learners' anxiety level and their beliefs about corrective feedback in oral communication classes. System, 42, 429-439. DOI: 10.1016/j.system. 2014.01.012 


\section{Yabancı dil olarak Tay dilini öğrenen üniversite öğrencilerin sözlü düzeltici geribildirim alg1ları ve tercihleri}

\section{Öz}

$\mathrm{Bu}$ araştırmanın amacı, Doğu Asya lisans öğrencileri arasında algıların ve tercihlerin varlığını araştırmaktır. $\mathrm{Bu}$ amaçla, beş üniversitede Tay dili konuşma kurslarına katılan 99 L2 öğrencisi, tanıma ve tutumları hakkında rapor veren çevrimiçi bir anket doldurdu. Bulgular, Tay dilini yabancı dil olarak öğrenen (TFL) öğrencilerine en sık sunulan sözlü düzeltici geri bildirim stratejisinin (OCF) recast olduğunu ortaya koydu. TFL öğretim durumlarında açık düzeltme en çok tercih edilen teknik olduğu bulundu. Bir konuşmada, öğrencilerin özel yerlerde hata düzeltmesi sağlanmaya eğilimli ve akranları tarafından düzeltilmek istedikleri görüldü. Ayrıca, Çinli ve Koreli öğrenciler arasındaki bazı OCF görüşlerinin benzer olduğunu; açıklama talebi ve tekrarlama tekniklerini tercih etme eğiliminde oldukları ortaya çıktı. Buna karşılık, hataya dikkatsizlik, akran düzeltmesi ve herkesin öününde hata düzeltmesi daha az tercih ettikleri görüldü.

Anahtar sözcükler: düzeltici geribildirim; algı; tercih; ikinci dil; Doğu Asya öğrencileri

\section{AUTHOR BIODATA}

Watcharapol Wiboolyasarin is currently an Associate Professor in Thai Language at Suan Dusit University where he teaches courses in BA language literacy and communication and supervises postgraduate students. He received his $\mathrm{PhD}$ in Educational Technology and Communications from Chulalongkorn University. His main research interests include Thai as a foreign language, language teaching, learning technology (instructional design, social media, and technology-enhanced language learning).

Kanokpan Wiboolyasarin is a lecturer in the Faculty of Management Science at Chandrakasem Rajabhat University, where she has been since 2013. She received a B Com Arts (Public Relations) (2nd class honors) from Burapha University, a B Com Arts (Radio) from Sukhothai Thammathirat Open University, and an MA (Communication Arts) from Chulalongkorn University. She recently received her PhD in Communicology, Thammasat University in 2019. Her research interests span both communication and language use.

Nattawut Jinowat is a lecturer on Thai language and culture at Demonstration School of Suan Sunandha Rajabhat University. He did his BA in Thai at Suan Dusit University. His areas of interest and research are in the Thai linguistics and currently his main research area is of corrective feedback. 